STUDIA I PRACE WYDZIAŁU NAUK EKONOMICZNYCH I ZARZĄDZANIA NR 39, t. 1

DOI:10.18276/sip.2015.39/1-02

\author{
Joanna Gajda* \\ Politechnika Częstochowska
}

\title{
ZARZĄDZANIE WIEKIEM I JEGO ZNACZENIE W STRATEGII SPOŁECZNEJ ODPOWIEDZIALNOŚCI BIZNESU
}

\section{Streszczenie}

Zarządzanie wiekiem łączy się ściśle ze strategią społecznej odpowiedzialności biznesu, gdyż zgodnie z jej zasadami organizacja jest zobowiązana do realizacji działań pozwalających na racjonalne wykorzystanie potencjału pracowników z różnych grup wiekowych. Jeżeli $\mathrm{w}$ miejscu pracy stworzy się pracownikom równe szanse, to stanie się to jednym $\mathrm{z}$ istotnych elementów prowadzących do budowy przewagi konkurencyjnej organizacji. Ważne jest przy tym, by każdy pracownik miał poczucie tego, że jest tak samo ważny dla organizacji niezależnie od posiadanej wiedzy, zajmowanego stanowiska czy lat pracy i życia. W artykule przedstawiono system zarządzania wiekiem, biorąc pod uwagę te obszary, na których jest on realizowany. Ponadto, zwrócono uwagę na przydatne narzędzia, które należy świadomie stosować w celu efektywnego zarządzania wiekiem pracowników. Zaprezentowane narzędzia wzajemnie się uzupełniają, tworząc system zintegrowanych działań, co pozytywnie przekłada się na funkcjonowanie organizacji. Ponieważ zagadnienia związane z zarządzaniem wiekiem są złożone i obejmują wiele aspektów, w artykule skoncentrowano się na problematyce dotyczącej wykorzystania potencjału pracowników określanych w literaturze przedmiotu jako 50+. Z uwagi na kryzys demograficzny, z którym boryka się Europa

*Adres e-mail: joannagajda@vp.pl. 
i także Polska, temat ten staje się niezwykle aktualny w kształtowaniu polityki kadrowej współczesnych organizacji.

Słowa kluczowe: zarządzanie wiekiem, społeczna odpowiedzialność biznesu, pracownik, organizacja

\section{Wprowadzenie}

Turbulentne otoczenie współczesnych organizacji sprawia, że mają one świadomość tego, że warunkiem osiągnięcia sukcesu na dynamicznie rozwijającym się rynku jest m.in. dążenie do pozyskania i utrzymania potencjału pracowników zróżnicowanych wiekowo. Wszelkie działania podejmowane w tym zakresie powinny być ważnym elementem polityki organizacji i obejmować różne fazy zatrudnienia pracownika - od rekrutacji po odejście z pracy. Pracownik w organizacji bardzo często spędza wiele lat, w każdym wieku zarówno on, jak i organizacja mają różne potrzeby i oczekiwania, problemy i role do zrealizowania, dlatego organizacja musi odpowiednio opracować i wdrożyć zarządzanie wiekiem pracowników. W zróżnicowanym wieku pracownik musi widzieć swoją przyszłość i potencjał swojego rozwoju. W niniejszym artykule podjęto próbę analizy systemu zarządzania wiekiem, łącząc go ze społeczną odpowiedzialnością biznesu z uwzględnieniem narzędzi wykorzystywanych przy jego wdrożeniu. Przy czym podkreślono zwłaszcza te instrumenty, które wykorzystuje się, aktywizując zawodowo pracowników 50+.

\section{Zarządzanie zasobami ludzkimi w kontekście społecznej odpowie- dzialności biznesu}

Literatura przedmiotu najczęściej podaje, że społeczna odpowiedzialność biznesu rozumiana jest jako strategia działań, która nie tylko skupia się na generowaniu i maksymalizowaniu zysków, ale także bierze pod uwagę interes społeczny i dobro interesariuszy, czyli uwzględnia w swoich działaniach aspekty prawne, kulturowe i etyczne ${ }^{1}$. W przypadku organizacji wykazujących odpowiedzialną postawę wyłania się kwestia moralna pozwalająca na rozstrzygnięcie dylematu - co jest dobre dla

1 J. Adamczyk, Spoleczna odpowiedzialność przedsiębiorstw. Teoria i praktyka, PWE, Warszawa 2009, s. 10. 
wszystkich jednostek i grup zainteresowanych możliwością wejścia z organizacją $\mathrm{w}$ interakcje, a co jest złe i niewłaściwe z punktu widzenia otoczenia organizacji. Jak stwierdza E. Michalski, tylko organizacja, która potrafi sprostać obowiązkom wobec własnego otoczenia, będzie w stanie ponieść gospodarczą i prawną odpowiedzialność za swoje działania i podejmowane decyzje².

Chcąc realizować cele własne oraz w stosunku do otoczenia, organizacja musi mieć opracowaną odpowiednią strategię oraz ludzi, którzy podejmą się różnych wyzwań. Ponieważ zadania i wyzwania w tym zakresie są złożone i różnorodne, oczywiste jest, że każdy pracownik organizacji może zostać wykorzystany i zaangażowany w działania przyczyniające się do wzrostu gospodarczego i osiągania zysku; także pracownicy zróżnicowani wiekiem. Warto zwrócić uwagę na fakt, że podwładni o wysokiej wydajności pracy bez względu na wiek uważani są za główne narzędzie wykorzystywane w celu generowania zysków. Przede wszystkim z tego powodu działania przedsiębiorców powinny być podejmowane w pierwszej kolejności wobec pracowników zróżnicowanych wiekowo i ściśle zintegrowane z CSR CS $^{3}$.

Zarządzanie zasobami ludzkimi w sposób odpowiedzialny jest obowiązkiem każdej z organizacji prowadzącej działalność gospodarczą, która charakteryzuje się poważnym podejściem do kwestii dotyczących CSR. Organizacja nie może sprawić, aby społeczna odpowiedzialność była jedynie narzędziem służącym do kreowania lub poprawy własnego wizerunku. Koncepcja CSR powinna stanowić fundament, na którym organizacja będzie mogła budować własną pozycję, ściśle ją łącząc z wartościami etycznymi ${ }^{4}$. Wdrażanie do codziennej praktyki cennych rozwiązań także z zakresu kultury, etyki czy prawa pozytywnie wpływa na morale pracowników, na poprawę wykonywanych obowiązków zawodowych i wzrost lojalności względem firm, staje się także ważnym elementem łączącym pracownika z organizacją na długie lata. Bezsprzecznie wpływa to także na efektywność ekonomiczną organizacji ${ }^{5}$.

2 E. Michalski, Zarzadzanie, Wydawnictwo Uczelniane Politechniki Koszalińskiej, Koszalin 2008, s. 33.

3 W. Worach, CSR w zarzadzaniu zasobami ludzkimi, www.kadry.abc.com.pl/czytaj/-/artykul/ csr-w-zarzadzaniu-zasobami-ludzkimi (25.01.2015).

4 K. Ruschak, Corporate Social Responsibility: Corporate Social Responsibility and the Theories it Generates from, (Diploma Thesis), GRIN Verlag, Santa Cruz 2012, s. 15.

5 K. Szydłowska-Biskup, Kultura etyczna $w$ firmie, http://biznesodpowiedzialnie.blog.pl/tag/ nutricia/ (25.01.2015). 


\section{Podstawowe obszary teoretyczne zarządzania wiekiem}

Rozważania dotyczące zarządzania wiekiem należy rozpocząć od próby określenia istoty tego terminu. Współcześnie zarządzanie wiekiem rozumiane jest jako zbiór przepisów, metod, instrumentów odnoszących się do zatrudnienia, zdolności do wykonywania pracy wpływających na osiągnięcie ekonomicznej i społecznej produktywności na przestrzeni całego życia oraz prowadzenie przez pracowników w każdym wieku zdrowego trybu życia z uwzględnieniem przy tym okresu emerytalnego ${ }^{6}$. Wszelkie działania podjęte $\mathrm{w}$ zakresie zarządzania wiekiem umożliwiają efektywne gospodarowanie potencjałem ludzkim, w tym także dojrzałych pracowników powyżej 50. roku życia7. Wśród propozycji wpisanych w filozofię zarządzania wiekiem szczególne miejsce zajmują działania sklasyfikowane w kilku następujących grupach ${ }^{8}$ :

- rekrutacja z zastosowaniem zasady niedyskryminowania pracowników ze względu na wiek,

- podnoszenie kwalifikacji w celu pozyskania nowych kompetencji,

- elastyczne formy zatrudnienia,

- planowanie stanowisk pracy i programy zdrowotne,

- rozwój i awans tzw. pracowników 50+,

- kończenie zatrudnienia i wejście w okres emerytalny.

Rekrutacja pracowników stanowi pierwszy, bardzo ważny element całej polityki zarządzania zasobami ludzkimi w organizacji. Wybierając pracownika i oceniając jego potencjał, zwraca się uwagę na jego przydatność do realizacji celów istotnych z punktu widzenia organizacji jako całości ${ }^{9}$. Chodzi tu o stan jego wiedzy i posiadane kompetencje, których potrzebuje organizacja. Do zaawansowanych działań prowadzonych w zakresie rekrutacji należą takie, które polegają na określeniu przez kadrę

${ }^{6}$ J. Field, R.J. Burke, C.L. Cooper, The Sage Handbook of Aging, Work and Society, Sage Publications, London 2013.

7 J. Liwiński, U. Sztanderska, Wstęne standardy zarządzania wiekiem w przedsiębiorstwach, w: Zarządzanie wiekiem w przedsiębiorstwie, red. J. Liwiński, U. Sztanderska, PARP, Warszawa 2010, s. 7.

8 A. Szcześniak, Dobre praktyki w zarządzaniu wiekiem i zasobami ludzkimi ze szczególnym uwzględnieniem pracowników 50+, red. A. Szcześniak, Warszawa 2013, s. 20-21, www.zostanmentorem.pl (25.01.2015).

9 D.M. Cable, Investigating Recruitment, The Oxford Handbook of Recruitment, Oxford University Press, New York 2013, s. 1. 
kierowniczą profili kompetencyjnych stanowisk pracy. Przygotowanie profili staje się okazją do sprecyzowania, które spośród kompetencji pracowniczych wymagane są na konkretnym stanowisku niezależnie od wieku ${ }^{10}$.

Nie ulega wątpliwości, że starsi pracownicy znajdują się w trudniejszej sytuacji, gdyż posiadane przez nich dotąd unikalne kompetencje mogły ulec dezaktualizacji w wyniku różnorodnych zmian w dziedzinie technologii, prawa itp., prowadząc tym samym do powstania deficytów wiedzy i umiejętności. Spadek poziomu kompetencji powoduje, że pracownicy tracą nadzieję na przedłużenie aktywności zawodowej i zaczynają czuć się niepewnie na rynku pracy, który preferuje młodość. Do takiego stanu rzeczy przyczyniają się niejednokrotnie panujące wśród przedsiębiorców uproszczone przekonania na ich temat. Pracodawcy podają w wątpliwość sens dalszego zatrudnienia osób powyżej 50. roku życia, twierdząc, że pracują oni mało wydajnie, wykazują brak zaufania wobec zmian, są negatywnie nastawieni do nowości technologicznych ${ }^{11}$. Są to powody, dla których właściciele firm tracą motywację do inwestowania w ich rozwój, co więcej - nawet rozważają zwolnienie ich z pracy. Aby zmienić ten niekorzystny trend, konieczne staje się odrzucenie stereotypowego wizerunku pracowników w starszym wieku i zwrócenie uwagi na korzyści wynikające $\mathrm{z}$ ich zatrudnienia. Przecież są to pracownicy z doświadczeniem, zdyscyplinowani i przede wszystkim znający organizację i jej otoczenie, umiejętnie poruszający się wśród procedur, zasad i regulaminów organizacyjnych. Jako przykład dobrych praktyk posłużyć mogą te firmy, które inwestują w szkolenia przeznaczone dla kadry zarządzającej, aby mogła ona w pełni kształtować swoją wiedzę oraz świadomość w zakresie zarządzania zespołem zróżnicowanym wiekowo.

Należy wyraźnie podkreślić, że w świadomości przedsiębiorców dostrzegających korzyści płynące z zatrudnienia tego typu pracowników niezbędne staje się także organizowanie szkoleń zawodowych mających na celu podwyższanie ich kwalifikacji zawodowych. Wobec powyższego za niezwykle istotne uważa się propagowanie idei kształcenia ustawicznego $\mathrm{z}$ wykorzystaniem następujących narzędzi ${ }^{12}$ :

10 Zarządzanie wiekiem - szansa dla przedsiębiorców. Mini przewodnik zarządzania wiekiem, Akademia Rozwoju Filantropii w Polsce, Warszawa 2010, s. 6.

11 P. Taylor, Older Workers in an Ageing Society: Critical Topics in Research and Policy, Edward Elgar Publishing, Chaltenham-Northampton 2013, s. 118.

12 J. Lewiński, U. Sztanderska, op.cit., s. 38. 
a) zapewnienie dostępu do szkoleń i innych form dokształcania wszystkim pracownikom bez względu na wiek;

b) motywowanie zwłaszcza dojrzałych wiekowo pracowników do kształcenia się, aby zrozumieli, że wiedza ulega dezaktualizacji, dlatego też niezbędne staje się podnoszenie kwalifikacji zawodowych z wykorzystaniem do tego celu dostępnych na rynku formy dokształcania - kursów, szkoleń, studiów uzupełniających itp.;

c) monitorowanie przebiegu szkoleń i udziału wszystkich pracowników niezależnie od wieku oraz zasobu kompetencji pracowniczych;

d) przygotowanie programu szkoleń z uwzględnieniem indywidualnej ścieżki kariery i rozwoju zawodowego pracownika; firma powinna zapewnić podwładnym dostęp do szkoleń przygotowujących do pracy na określonym stanowisku i przyczyniających się do rozwoju kariery zawodowej;

e) prowadzenie na bieżąco analizy porównawczej potrzeb kompetencyjnych organizacji i kompetencji pracowników, jak również oparcie tematyki szkoleń na zdiagnozowanych deficytach; wymagane jest prowadzenie takich działań regularnie ze względu na dezaktualizowanie się kompetencji nawet po upływie 3 lat;

f) zintegrowanie metod, miejsca i czasu szkolenia z potrzebami pracowników dojrzałych wiekowo;

g) wprowadzenie ograniczenia czasu pracy podczas szkolenia;

h) organizowanie pracy w taki sposób, aby sprzyjała procesowi uczenia się - tworzenie zespołów, których członkami są pracownicy w różnym wieku (pozwala to na wykorzystanie dwustronnego mentoringu, w ramach którego młodsi pracownicy przekazują starszym kolegom wiedzę z zakresu nowoczesnych technologii, a z kolei dojrzali wiekiem pracownicy mogą przekazać młodszym doświadczenia wyniesione z pracy);

i) przygotowanie działań mających na celu analizowanie efektów kształcenia.

W ramach strategii zarządzania wiekiem ważne jest uwzględnienie zasad elastycznych form zatrudnienia dotyczących nietypowych stosunków pracy ${ }^{13}$. Zastosowanie elastycznych form zatrudnienia wobec starszych pracowników zakłada

13 J.W. Hedge, W.C. Borman, The Oxford Handbook of Work and Aging, Oxford University Press, New York 2012, s. 410. 
dostosowanie czasu pracy do ich aktualnych potrzeb i możliwości. W celu uelastycznienia czasu pracy ustala się takie godziny pracy, które sprzyjają zwiększeniu efektywności pracowników i godzeniu pracy zawodowej z życiem osobistym czy innymi wyzwaniami związanymi z wiekiem. Starsi pracownicy wykazują zainteresowanie elastycznym czasem pracy choćby z takich powodów, jak: mniejsza sprawność fizyczna, obowiązki opiekuńcze wobec rodziny, ochrona przed zawieszeniem emerytury ${ }^{14}$. W przypadku starszych pracowników uzasadnione jest zastosowanie następujących form zatrudnienia: praca na niepełny etat, skrócony wymiar czasu pracy, praca zdalna, w tym telepraca, praca na wezwanie, praca zmianowa, ruchomy czas pracy, praca tymczasowa.

Nie można jednoznacznie stwierdzić, że wraz z wiekiem pojawiają się ograniczenia we wszystkich obszarach pracy zawodowej człowieka dotyczące zdolności realizacji zadań na określonym stanowisku. Zmniejszająca się sprawność fizyczna może być kompensowana poprzez: duże doświadczenie, wiedzę, wysoką odporność emocjonalną ${ }^{15}$. Warto zatem pamiętać, że w celu przedłużenia okresu aktywności zawodowej pracowników za konieczne uznaje się zapewnienie bezpiecznych warunków pracy w organizacji. Aby spełnić powyższy cel, należy zadbać o dostosowanie stanowisk pracy do możliwości i potrzeb osobistych wszystkich pracowników niezależnie od wieku ${ }^{16}$.

W ramach dobrych praktyk zarządzania wiekiem istotny element stanowią działania ukierunkowane na ochronę zdrowia. Ich adresatami powinni być wszyscy pracownicy bez względu na wiek, ale w strategii organizacji powinno uwzględnić się specyficzne potrzeby pracowników dojrzalszych wiekiem, których problemy zdrowotne mogą istotnie ograniczać wykonywane zadania. Dobrym rozwiązaniem może być stosowanie zachęt skłaniających do inwestowania w dodatkowe ubezpieczenia zdrowotne i wypadkowe na korzystnych warunkach. Kluczowe znaczenie mają szkolenia organizowane w celu uświadomienia pracownikom korzyści, z któ-

14 J. Liwiński, U. Sztanderska, Wstępne standardy zarządzania..., s. 14.

15 P. Cappelli, B. Novelli, Managing the Older Worker: How to Prepare for the New Organizational Order, Harvard Business Press, Cambridge 2013, s. 29.

16 A. Polak-Sopińska, Adaptacja stanowisk pracy do możliwości i potrzeb pracowników 50+, w: Człowiek - najlepsza inwestycja. Metodyka zarzadzania wiekiem jako innowacyjne rozwiazanie wspierające aktywność zawodowa pracowników 50+, red. P. Woszczyk, M. Czarnecka, HRP, Łódź 2013, s. 141. 
rymi wiąże się osiągnięcie wieku 50+, a zarazem zagrożeń dla ich zdrowia podczas wykonywanej pracy ${ }^{17}$.

W przypadku mogących pojawić się problemów zdrowotnych u pracownika stosowane są przesunięcia na takie stanowiska, na których pracownik będzie mógł wykonywać swoje obowiązki bez ograniczeń spowodowanych wiekiem, chorobą czy niepełnosprawnością. Działania oparte na przesunięciach mogą także pełnić rolę prewencyjną, a podejmowane są w celu zapobiegania powstawaniu chorób zawodowych. Wskazane jest, aby pracodawcy skupili się na przygotowaniu pracownikowi stanowiska pracy odpowiadającego jego możliwościom psychofizycznym. Stworzenie pracownikom dogodnych warunków pracy sprawia, że w mniejszym stopniu czują się oni obciążeni pracą, co w efekcie prowadzi do uniknięcia wypalenia zawodowego ${ }^{18}$.

Od kilku lat firmy borykają się z problemem niedoboru wykwalifikowanych pracowników. Mówi się nawet o ogólnoświatowym deficycie talentów, co sprawia, że firmy muszą sprostać trudnemu wyzwaniu, a mianowicie poradzić sobie z pozyskiwaniem pracowników, na których im najbardziej zależy. W takiej sytuacji niektóre spośród firm decydują się na przyjęcie strategii działań koncentrującej się na pracownikach dojrzałych wiekowo. W kontekście koncepcji zarządzania wiekiem można zaryzykować stwierdzenie, że zagwarantowanie pracownikom możliwości rozwoju zawodowego stanowi dla nich zachętę do pozostania $\mathrm{w}$ danej firmie przez następne kilkanaście lat ${ }^{19}$. Analizując skuteczność rozwiązań w zakresie zarządzania karierą zawodową pracowników dojrzałych wiekowo, na uwagę zasługują te, które sprzyjają osiągnięciu wysokiej pozycji w danej organizacji i zadowoleniu z pracy. Działania w tym zakresie podejmowane w dużych korporacjach to ${ }^{20}$ :

- udzielanie informacji zwrotnej na temat efektów pracy,

- zwiększenie odpowiedzialności,

- zaproponowanie nowego stanowiska,

- coaching,

17 A. Zięba, A. Szuwarzyński, 50 + zarządzanie wiekiem, Politechnika Gdańska. Wydział Zarządzania i Ekonomii, Gdańsk 2008, s. 62.

18 J. Liwiński, J. Sztanderska, Wstępne standardy zarządzania..., s. 66.

19 M. Gawron, J. Milewska, Rozwój i awans pracowników w wieku 50 plus, w: Człowiek-najlepsza inwestycja. Metodyka zarządzania wiekiem jako innowacyjne rozwiazanie wspierające aktywność zawodową pracowników 50+, red. P. Woszczyk, M. Czarnecka, HRP, Łódź 2013, s. 87.

20 Ibidem, s. 93. 
- zostanie trenerem/mentorem,

- tworzenie baz wiedzy,

- przydzielanie nowych zadań,

- opiniowanie działań strategicznych,

- szkolenia.

Dobre praktyki można także odnieść do dziedziny związanej z zakończeniem zatrudnienia i odejściem na emeryturę. Zgodnie z założeniem dobrych praktyk, decyzje o zwolnieniu pracownika muszą być oparte na obiektywnych kryteriach w odniesieniu do konkretnego pracownika. Natomiast przejścia na emeryturę nie należy utożsamiać z przymusem, powinno być kwestią wyboru dokonanego przez pracownika ${ }^{21}$. Pracodawca, podejmując decyzję o zwolnieniu pracownika, nie może brać pod uwagę wieku, lecz kierować się jego wiedzą, umiejętnościami i wydajnością pracy. W kontekście zarządzania wiekiem dobrą praktyką są też programy wsparcia pracowników polegające na wykorzystaniu metody outplacementu, której istotą jest świadczenie pomocy osobie poszukującej nowego miejsca pracy oraz stworzenie systemu doradztwa zawodowego ${ }^{22}$. Organizacja, której pracownik poświęcił wiele lat swego życia, umiejętności i wiedzę, powinna także w momencie jej opuszczenia przez pracownika pomóc odnaleźć się w nowych warunkach.

\section{Podsumowanie}

W dobie procesu starzenia się społeczeństwa i malejącej liczby młodych pracowników wchodzących na rynek pracy istnieje potrzeba poszukiwania nowego podejścia do zarządzania zasobami ludzkimi z uwzględnieniem problematyki zarządzania wiekiem. W związku z tym konieczne staje się podejmowanie działań mających na celu zachęcanie osób dojrzałych wiekiem do pozostania w firmie i zwiększenia ich wydajności pracy, podjęcia działań w zakresie podnoszenia swoich kompetencji. Dbałość o efektywne wykorzystanie potencjału wszystkich zatrudnionych osób i utrzymanie ich maksymalnej aktywności wpływa na wzrost skuteczności w procesie osiągania celów organizacyjnych. Przegląd literatury przedmiotu dostarcza wielu

${ }^{21}$ J. Liwiński, U. Sztanderska, Kończenie zatrudnienia i przechodzenie na emeryture, Wydawnictwo Uniwersytetu Warszawskiego, Warszawa 2010, s. 10.

22 M. Kuciński, M. Rutkiewicz, Zarządzanie wiekiem sposobem aktywizacji osób 50+, Wydawnictwo Kujawsko-Pomorskiej Szkoły Wyższej w Bydgoszczy, Bydgoszcz 2012, s. 61. 
przykładów dobrych praktyk potwierdzających zasadność stosowania narzędzi zarządzania wiekiem sprzyjających efektywnemu wykorzystaniu potencjału ludzkiego w organizacji. To przecież ludzie decydują o sukcesie organizacji, jej wizerunku i roli, jaką odgrywa w społeczeństwie.

\section{Literatura}

Adamczyk J., Spoteczna odpowiedzialność przedsiębiorstw. Teoria i praktyka, PWE, Warszawa 2009.

Cable D.M., The Oxford Handbook of Recruitment, Oxford University Press, New York 2013.

Cappelli P., Novelli B., Managing the Older Worker: How to Prepare for the New Organizational Order, Harvard Business Press, Cambridge 2013.

Dobre praktyki w zarządzaniu wiekiem i zasobami ludzkimi ze szczególnym uwzględnieniem pracowników 50+, red. A. Szcześniak, Warszawa 2013, www.zostanmentorem.pl (25.01.2015).

Gawron M., Milewska J., Rozwój i awans pracowników w wieku 50 plus, w: Człowiek najlepsza inwestycja. Metodyka zarzadzania wiekiem jako innowacyjne rozwiazanie wspierajace aktywność zawodowa pracowników 50+, red. P. Woszczyk, M. Czarnecka, HRP, Łódź 2013.

Field J., Burke R.J., Cooper L.C., The Sage Handbook of Aging, Work and Society, Sage Publications, London 2013.

Hedge J.W., Borman W.C., The Oxford Handbook of Work and Aging, Oxford University Press, New York 2012.

Kuciński M., Rutkiewicz M., Zarządzanie wiekiem sposobem aktywizacji osób 50+, Wydawnictwo Kujawsko-Pomorskiej Szkoły Wyższej w Bydgoszczy, Bydgoszcz 2012.

Liwiński J., Sztanderska U., Kończenie zatrudnienia $i$ przechodzenie na emeryture, Wydawnictwo Uniwersytetu Warszawskiego, Warszawa 2010.

Liwiński J., Sztanderska U., Wstęne standardy zarządzania wiekiem w przedsiębiorstwach, w: Zarzadzanie wiekiem $w$ przedsiębiorstwie, red. J. Liwiński, U. Sztanderska, PARP, Warszawa 2010.

Michalski E., Zarządzanie, Wydawnictwo Uczelniane Politechniki Koszalińskiej, Koszalin 2008.

Polak-Sopińska A., Adaptacja stanowisk pracy do możliwości i potrzeb pracowników 50+, w: Człowiek-najlepsza inwestycja. Metodyka zarzadzania wiekiem jako innowacyjne 
rozwiqzanie wspierajace aktywność zawodowa pracowników 50+, red. P. Woszczyk, M. Czarnecka, HRP, Łódź 2013.

Ruschak K., Corporate Social Responsibility: Corporate Social Responsibility and the Theories it Generates From, (Diploma Thesis), GRIN Verlag, Santa Cruz 2012.

Szydłowska-Biskup K., Kultura etyczna w firmie, http://biznesodpowiedzialnie.blog.pl/tag/ nutricia/ (25.01.2015).

Taylor P., Older Workers in an Ageing Society: Critical Topics in Research and Policy, Edward Elgar Publishing, Chaltenham-Northampton 2013.

Worach W., CSR w zarzqdzaniu zasobami ludzkimi, www.kadry.abc.com.pl/czytaj/-/artykul/ csr-w-zarzadzaniu-zasobami-ludzkimi (25.01.2015).

Zarządzanie wiekiem - szansa dla przedsiębiorców. Mini przewodnik zarządzania wiekiem, Akademia Rozwoju Filantropii w Polsce, Warszawa 2010.

Zięba A., Szuwarzyński A., 50+ zarzadzanie wiekiem, Politechnika Gdańska. Wydział Zarządzania i Ekonomii, Gdańsk 2008.

\title{
AGE MANAGEMENT AND ITS ROLE IN THE STRATEGY OF CORPORATE SOCIAL RESPONSIBILITY
}

\begin{abstract}
Age management is closely connected to the strategy of corporate social responsibility, because, according to its principles, organization is required to implement measures to make rational use of the potential of employees from different age groups. If the workplace creates equal opportunities for workers, it will become one of the essential elements leading to building the competitive advantage of the organization. At the same time, it is important for the employees to have the feeling that they are important for the organization regardless of their knowledge, their position or years of work and life. This article presents the agemanagement system, taking into account those areas in which it is implemented. In addition, attention is drawn to useful tools that should be consciously used to effectively manage the age of employees. Presented tools complement each other, creating a system of integrated activities, which is positively reflected in the functioning of the organization. Since the issues related to age management are complex and involve many aspects, this article focuses on issues relating to the potential of employees referred to as $50+$ in the literature. Due to the
\end{abstract}


demographic crisis faced by the Europe and Poland, this issue becomes highly relevant in shaping the personnel policy of modern organizations.

Translated by Joanna Gajda

Keywords: age management, corporate social responsibility, employee, organization JEL Code: M12 